\title{
Effect of Genistein in Comparison with Trichostatin A on Reactivation of DNMTs Genes in Hepatocellular Carcinoma
}

\author{
Masumeh Sanaei ${ }^{1}$, Fraidoon Kavoosi*1 ${ }^{1}$, Abazar Roustazadeh ${ }^{1}$ and Fatemeh Golestan ${ }^{2}$ \\ ${ }^{1}$ Research Center for Non-Communicable Diseases, Jahrom University of Medical Sciences, Jahrom, Fars province, Iran; \\ ${ }^{2}$ Student Research Committee, Jahrom University of Medical Sciences, Jahrom, Fars province, Iran
}

\begin{abstract}
Background and Aims: DNA methylation and histone modification are epigenetic modifications essential for normal function of mammalian cells. The processes are mediated by biochemical interactions between DNA methyltransferases (DNMTs) and histone deacetylases. Promoter hypermethylation and deacetylation of tumor suppressor genes play major roles in cancer induction, through transcriptional silencing of these genes. DNA hypermethylation is carried out by a family of DNMTs including DNMT1, DNMT3a and DNMT3b. In hepatocellular carcinoma, a significant positive correlation between over-expression of these genes and cancer induction has been reported. The DNA demethylating agent genistein (GE) has been demonstrated to reduce different cancers. Previously, we reported that GE can induce apoptosis and inhibit proliferation in hepatocellular carcinoma PLC/PRF5 and HepG2 cell lines. Besides, histone deacetylase inhibitors, such as trichostatin A (TSA), were successfully used to inhibit cancer cell growth. The present study was designed to assess the effect of GE in comparison with TSA on DNMT1, DNMT3a and DNMT3b gene expression, cell growth inhibition and apoptosis induction in the HepG2 cell line. Methods: Cells were seeded and treated with various doses of GE and TSA. The MTT assay, flow cytometry assay, and real-time RT-PCR were used to determine viability, apoptosis, and DNMT1, DNMT3a and DNMT3b gene expression respectively. Results: Both agents inhibited cell growth, induced apoptosis and reactivated DNMT1, DNMT3a and DNMT3b gene expression. Furthermore, TSA demonstrated a significantly greater apoptotic effect than the other agent, whereas GE improved gene expression more significantly than TSA. Conclusions: Our findings suggest that GE and TSA can significantly inhibit cell growth, induce apoptosis and restore DNMT1, DNMT3a and DNMT3b gene reactivation.
\end{abstract}

Citation of this article: Sanaei M, Kavoosi F, Roustazadeh A, Golestan F. Effect of genistein in comparison with trichostatin A on reactivation of DNMTs genes in hepatocellular carcinoma.

Keywords: Genistein; Trichostatin A; DNA methyltransferases; Apoptosis; Hepatocellular carcinoma.

Abbreviations: DMEM, Dulbecco's modified Eagle's medium; DMSO, dimethyl sulfoxide; DNMT, DNA methyltransferase; $\mathrm{GE}$, genistein; $\mathrm{IC}_{50}$, half maximal inhibitory concentration; HCC, hepatocellular carcinoma; HDAC, histone deacetylase; $\mathrm{HDACI}$, histone deacetylase inhibitor; MTT, 5-diphenyl-2H-tetrazolium bromide; PBS, phosphate-buffered saline; PCR, polymerase chain reaction; TSA, trichostatin A; TSG, tumor suppressor gene.

Received: 5 January 2018; Revised: 26 January 2018; Accepted: 31 January 2018 *Correspondence to: Fraidoon Kavoosi, Jahrom University of Medical Sciences, Jahrom, Fars province, 74148-46199, Iran. Tel: +98-9173914117, E-mail: kavoosifraidoon@gmail.com
J Clin Transl Hepatol 2018;6(2):141-146. doi: 10.14218/ JCTH.2018.00002.

\section{Introduction}

DNA methylation and histone modification are epigenetic modifications essential for normal function of mammalian cells. Both of these processes are dependent on one another, and crosstalk between these two processes work hand-inhand and are mediated by biochemical interactions between histone deactylases (HDACs) and DNA methyltransferases (DNMTs). It is well characterized that an aberrant methylation of gene promoter regions is associated with loss of gene function. In fact, the level and patterns of DNA methylation and histone acetylation are altered in human cancers. However, promoter hypermethylation and deacetylation of tumor suppressor genes (TSGs) play major roles in cancer induction, through transcriptional silencing of these genes.

Each cancer subtype has specific tumor suppressor genes that are commonly susceptible to hypermethylation and silencing. ${ }^{1}$ DNA hypermethylation is performed by a family of DNMTs including DNMT1, DNMT3a and DNMT3b. In hepatocellular carcinoma (HCC), a significant positive correlation between over-expression of DNMT1, DNMT3a and DNMT3b and cancer induction has been reported. ${ }^{2}$ Finally, DNA hypermethylation is associated with chromatin compaction, resulting in gene silencing.

The DNA demethylating agent genistein (GE), a soyderived isoflavone, has been demonstrated to reduce different cancers, such as prostate cancer, ${ }^{3}$ colon cancer, ${ }^{4}$ ovarian cancer $^{5}$ and MDA-MB-231 breast cancer. ${ }^{6}$ Previously, we reported that GE can induce apoptosis and inhibit proliferation in the HCC cell lines of PLC/PRF5 ${ }^{7}$ and HepG2. ${ }^{8}$ Other previous studies indicated that GE can inhibit cell growth and induce apoptosis in numerous types of cancers through various mechanisms, including the regulation of cell cycle progression, ${ }^{9,10}$ suppression of the secretion of matrix metalloproteinases, ${ }^{11}$ inhibition of kinase and protease activities, ${ }^{12,13}$ and inhibition of the induction of activator protein-1 activity. ${ }^{14}$

Histone deacetylase inhibitors have been used successfully to inhibit cancer cell growth in vitro. Histones are basic proteins that form nucleosomes, the basic unit of chromatin, in complexes with DNA, resulting in chromatin compaction. Basic amino acids of the histones are modified posttranslationally with ubiquitin or with methyl, acetyl or phosphate groups. Indeed, acetylation of lysine residues of the histones weakens their binding to DNA, which in turn induces a change of DNA conformation. This conformational change is essential 
for binding of transcription factors to the promoter regions of regulatory genes (e.g., cell cycle regulatory genes)..$^{15-17}$

Histone deacetylase inhibitors (HDACIs) seem to be a new class of anticancer agents and have emerged as attractive candidates for cancer therapy. In different cancers, overactivation of the HDACs results in histone hypoacetylation. It has recently been reported that HDACIs induce growth arrest, differentiation and apoptosis of cancer cells by altering the acetylation status of an array of substrates, including transcription factors, histones and chaperone proteins. ${ }^{18-20}$ Trichostatin A (TSA) is one of the most common HDACIs that affect numerous cancers. It blocks proliferation and triggers apoptotic programs in hepatoma HepG2, MH1C1, Hepa1-6 and Hep1B cells. ${ }^{21}$

Our previous finding clearly indicates that GE and TSA inhibit cell growth, induce apoptosis and reactivate ER $\alpha$ gene expression. ${ }^{22}$ For lung cancer, it has also been reported that GE enhances the growth inhibition and apoptotic effect of TSA in human lung carcinoma A549 cells. ${ }^{23,24}$

\section{Objectives}

With regard to the previous results of our group and others, the present study was designed to assess the effect of GE and TSA on DNMT1, DNMT3a and DNMT3b gene expression, cell growth inhibition and apoptosis induction in the hepatocellular carcinoma HepG2 cell line.

\section{Methods}

\section{Materials}

Human HCC HepG2 cells were purchased from the National Cell Bank of Iran-Pasteur Institute and maintained in Dulbecco's modified Eagle's medium (DMEM) containing $100 \mathrm{~mL} / \mathrm{L}$ fetal bovine serum, $100 \mathrm{U} / \mathrm{mL}$ penicillin, $100 \mathrm{U} / \mathrm{mL}$ streptomycin at $37^{\circ} \mathrm{C}$ in a humidified atmosphere containing $50 \mathrm{~mL} / \mathrm{L}$ $\mathrm{CO}_{2}$. TSA and GE were purchased from Sigma (St. Louis, MO, USA) and dissolved in dimethyl sulfoxide (DMSO; Sigma) at a final concentration of $100 \mu \mathrm{M}$ in order to prepare a stock solution. By diluting the stock solution, all of the other test concentrations were prepared. DMEM, DMSO, 3-[4,5-dimethyl2-thiazolyl]-2, 5-diphenyl-2H-tetrazolium bromide (MTT) and phosphate-buffered saline (PBS) were purchased from Sigma. Total RNA extraction kit (TRIZOL reagent) and real-time polymerase chain reaction (PCR) kits (qPCR MasterMix Plus for SYBR Green I dNTP) were obtained from Applied Biosystems Inc. (Foster, CA, USA).

\section{MTT cell proliferation assay}

HepG2 cells were cultured and grown in DMEM supplemented with $10 \%$ fetal bovine serum. After $24 \mathrm{~h}$, the cells were trypsinized and seeded in 96-well plates at a density of $5 \times$ $10^{5}$ cells/well and cultured for another $24 \mathrm{~h}$ before incubation with a certain concentration of GE and TSA. Then, the attached cells were treated with GE $(1,10,20,40$ and $50 \mu \mathrm{M})$ and TSA $(0.5,1,5,10$ and $20 \mu \mathrm{M})$ and incubated at $37^{\circ} \mathrm{C}$ in $5 \% \mathrm{CO}_{2}$ for 24,48 and $72 \mathrm{~h}$. Control cell groups received equal amounts of DMSO in the medium. At the end of treatment times, the cells were washed twice with PBS, and a fresh medium containing MTT $(0.5 \mathrm{mg} / \mathrm{mL})$ was added. Following a 4-h incubation, the medium was aspirated and 100 $\mu \mathrm{L}$ DMSO was added into each well. The plates were mixed gently by rocking back and forth until the blue formazan crystals were completely dissolved. Finally, the absorbance of the cells was measured at $570 \mathrm{~nm}$.

\section{Determination of gene expression by real-time quantitative RT-PCR}

To determine DNMT1, DNMT3a and DNMT3b gene expression, the cells were treated with GE $(22 \mu \mathrm{M})$ and TSA $(1.5 \mu \mathrm{M})$ for different time periods (24, 48 and $72 \mathrm{~h}$ ); using an MTT assay, the half maximal inhibitory concentration (IC50) of GE was determined to be $\sim 22 \mu \mathrm{M}$, and of TSA to be $\sim 1.5 \mu \mathrm{M}$. After treatment times, total RNA of the treated and control cells was extracted using the RNeasy Mini Kit (Qiagen, Valencia, CA, USA) according to the manufacturer's protocol and then pretreated with RNase-free DNase (Qiagen) to remove the genomic DNA prior to cDNA synthesis. The RNA concentration was determined using a Biophotometer (Eppendorf, Hamburg, Germany).

Total RNA (100 ng) was reverse transcribed to cDNA using the RevertAid ${ }^{\text {TM }}$ First Strand CDNA Synthesis Kit (Fermentas, Thermo Fisher Scientific, Waltham, MA, USA) according to the manufacturer's instructions. Real-time RT-PCR was performed with the Maxima SYBR Green ROX qPCR Master Mix Kit (Fermentas). DNMT1, DNMT3a and DNMT3b primers were obtained from the literature; ${ }^{25,26}$ their sequences are shown in Table 1. GAPDH was used as an endogenous control. Realtime PCR reactions were performed using StepOnePlus (Applied Biosystems Inc.). Thermal cycling conditions were: initial denaturation at $92^{\circ} \mathrm{C}$ for $12 \mathrm{~m}$, followed by 35 cycles of denaturation at $92^{\circ} \mathrm{C}$ for $25 \mathrm{~s}$, annealing at $58^{\circ} \mathrm{C}$ for $20 \mathrm{~s}$ and extension at $72^{\circ} \mathrm{C}$ for $20 \mathrm{~s}$. Data were analyzed using the comparative Ct $(\Delta \Delta \mathrm{ct})$ method, the relative expression level of DNMT1, DNMT3a and DNMT3b were calculated by determining a ratio between the amount of these genes and that of endogenous control.

\section{Flow cytometric analysis of apoptotic cells}

To determine the apoptotic effect of GE and TSA, the cells were seeded in triplicate in 24-well plates at the density of $5 \times 10^{5} /$ well. After $24 \mathrm{~h}$ of seeding, the medium was replaced with medium containing GE $(22 \mu \mathrm{M})$ and TSA $(1.5 \mu \mathrm{M})$ for different time periods (24, 48 and $72 \mathrm{~h}$ ) except for the control groups which received DMSO (0.01-0.3\%). After treatment times, all the adherent cells were harvested and collected by trypsinization and then centrifuged, washed twice with PBS and resuspended in binding buffer $(1 \times)$.

Table 1. Real-time PCR primers used in the study

\begin{tabular}{ll}
\hline Primer name & Primer sequences (5' to $3^{\prime}$ ) \\
\hline DNMT1 Forward & GAG GAA GCT GCT AAG GAC TAG TTC \\
DNMT1 Reverse & ACT CCA CAA TIT GAT CAC TAA ATC \\
DNMT-3A & GGA GGC TGA GAA GAA AGC CAA \\
Forward & GGT \\
$\begin{array}{l}\text { DNMT-3A } \\
\text { Reverse }\end{array}$ & TIT GCC GTC TCC GAA CCA CAT GAC \\
DNMT3b Forward & TAC ACA GAC GTG TCC AAC ATG GGC \\
DNMT3b Reverse & GGA TGC CTT CAG GAA TCA CAC CTC \\
\hline
\end{tabular}


Finally, annexinV-FITC and propidium iodide (Becton-Dickinson, San Diego, CA, USA) were added and analysis was carried out according to the manufacturer's protocol (BMS500F1/ 100CE annexinV-FITC; eBioscience, San Diego, CA, USA). All experiments were processed independently three times.

\section{Results}

\section{In vitro effects of GE and TSA on HepG2 cell growth}

The HepG2 cells were incubated with different concentrations of GE and TSA at different time periods, as mentioned above. Antiproliferative effects of the compounds were evaluated by MTT assay, which indicated that these compounds can inhibit proliferation of HepG2 cells significantly better than cells in control groups. As shown in Figure 1, GE and TSA significantly inhibited cell growth with all concentrations used $(p<0.003$ and $p<0.002$ respectively). IC50 values for GE and TSA were $\sim 22 \mu \mathrm{M}$ and $\sim 1.5 \mu \mathrm{M}$ respectively.

\section{Effects on DNMT1, DNMT3a and DNMT3b gene expression}

To characterize the effect of GE and TSA on HepG2 mRNA expression, real-time RT-PCR was carried out. The results indicated that GE significantly down-regulated DNMT1 ( $p<$ $0.001)$ and DNMT3a gene expression $(p<0.002)$ at different time periods (24, 48 and $72 \mathrm{~h}$ ) and DNMT3b gene expression after $48 \mathrm{~h}(p<0.003)$ and $72 \mathrm{~h}(p<0.002)$ versus control groups, whereas TSA down-regulated DNMT1 gene expression after $48 \mathrm{~h}(p<0.006)$ and $72 \mathrm{~h}(p<0.001)$ and DNMT3a gene expression only after $72 \mathrm{~h}(p<0.002)$. In fact, TSA had no significant effect on DNMT1 gene expression after $24 \mathrm{~h}$, DNMT3a gene expression after 24 and $48 \mathrm{~h}$, and DNMT3b gene expression after different time periods (24, 48 and $72 \mathrm{~h}$ ). The relative expression of DNMT1, DNMT3a and DNMT3b genes is shown in Table 2. As indicated in Figure 2, DNMT1 gene expression in the group treated with GE at $72 \mathrm{~h}$ was minimal, meaning that maximal inhibition was seen with GE on DNMT1 after $72 \mathrm{~h}$.

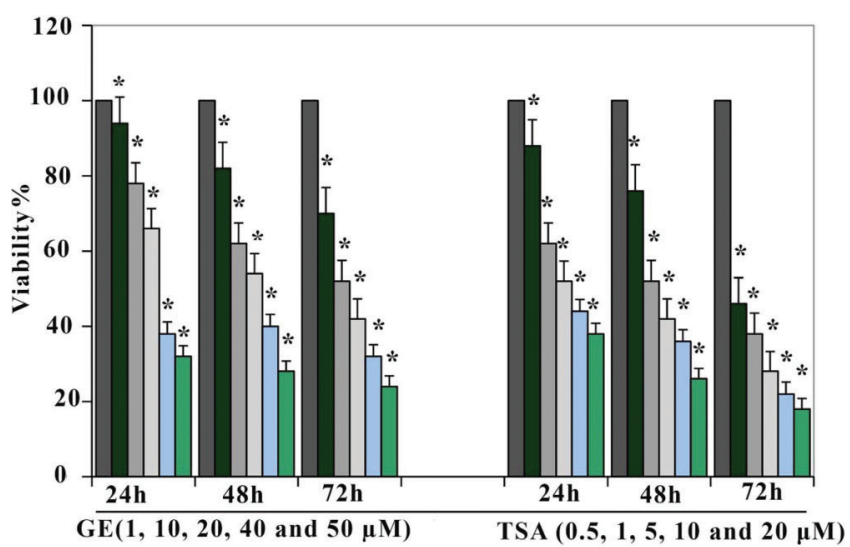

Fig. 1. Effect of GE and TSA on HepG2 cell viability determined by MTT assay. Data are presented as mean \pm standard deviation from at least triplicate wells and three independent experiments. Asterisks $\left({ }^{*}\right)$ indicate significant differences between treated cells and the control group. The first column of each group belongs to the control group.
Table 2. Relative expression level of DNMT1, DNMT3a and DNMT3b

\begin{tabular}{llllll}
\hline Gene & Drug & $\begin{array}{l}\text { Dose } \\
(\mu \mathrm{M})\end{array}$ & $\begin{array}{l}\text { Duration } \\
(\mathrm{h})\end{array}$ & Expression & $\mathrm{p}$-value \\
\hline DNMT1 & GE & 22 & 24 & 0.31 & $\mathrm{p}<0.001$ \\
DNMT1 & GE & 22 & 48 & 0.23 & $\mathrm{p}<0.001$ \\
DNMT1 & GE & 22 & 72 & 0.15 & $\mathrm{p}<0.001$ \\
DNMT3a & GE & 22 & 24 & 0.35 & $\mathrm{p}<0.002$ \\
DNMT3a & GE & 22 & 48 & 0.26 & $\mathrm{p}<0.002$ \\
DNMT3a & GE & 22 & 72 & 0.23 & $\mathrm{p}<0.002$ \\
DNMT3b & GE & 22 & 24 & 0.63 & $\mathrm{p}<0.018$ \\
DNMT3b & GE & 22 & 48 & 0.51 & $\mathrm{p}<0.030$ \\
DNMT3b & GE & 22 & 72 & 0.31 & $\mathrm{p}<0.001$ \\
DNMT1 & TSA & 1.5 & 24 & 0.57 & $\mathrm{p}<0.077$ \\
DNMT1 & TSA & 1.5 & 48 & 0.41 & $\mathrm{p}<0.006$ \\
DNMT1 & TSA & 1.5 & 72 & 0.32 & $\mathrm{p}<0.001$ \\
DNMT3a & TSA & 1.5 & 24 & 0.87 & $\mathrm{p}<0.891$ \\
DNMT3a & TSA & 1.5 & 48 & 0.65 & $\mathrm{p}<0.236$ \\
DNMT3a & TSA & 1.5 & 72 & 0.36 & $\mathrm{p}<0.002$ \\
DNMT3b & TSA & 1.5 & 24 & 0.97 & $\mathrm{p}<0.001$ \\
DNMT3b & TSA & 1.5 & 48 & 0.8 & $\mathrm{p}<0.858$ \\
DNMT3b & TSA & 1.5 & 72 & 0.65 & $\mathrm{p}<0.236$ \\
\hline
\end{tabular}

\section{Effects on cell apoptosis}

To detect the apoptotic cells by flow cytometry assay after 24 , 48 and $72 \mathrm{~h}, \mathrm{GE}-(22 \mu \mathrm{M})$ and TSA- $(1.5 \mu \mathrm{M})$ treated cells, and control cells, were assessed by flow cytometry, which indicated that GE and TSA induced apoptosis significantly in all treatment groups versus control groups (Fig. 3). The percentage of apoptotic cells is indicated in table 3. Relative analysis between GE and TSA treatment groups at different times indicated that TSA induced apoptosis more significantly than GE.

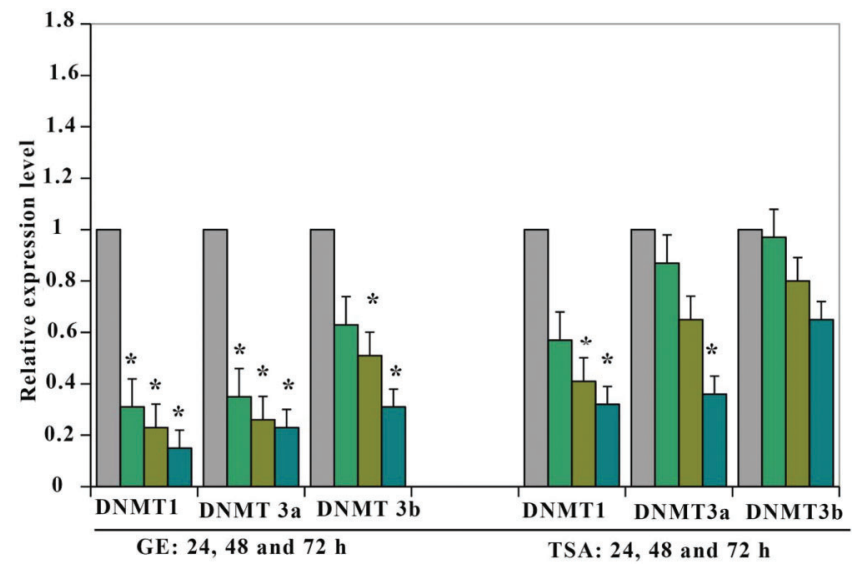

Fig. 2. Relative expression levels of DNMT1, DNMT3a and DNMT3b. Data are presented as mean \pm standard error of the mean from at least three different experiments. Asterisks $(*)$ indicate significant differences between treated cells and the control group. First column of each group belongs to the control group. 
Sanaei M. et al: Epigenetic reactivation of DNMTs genes
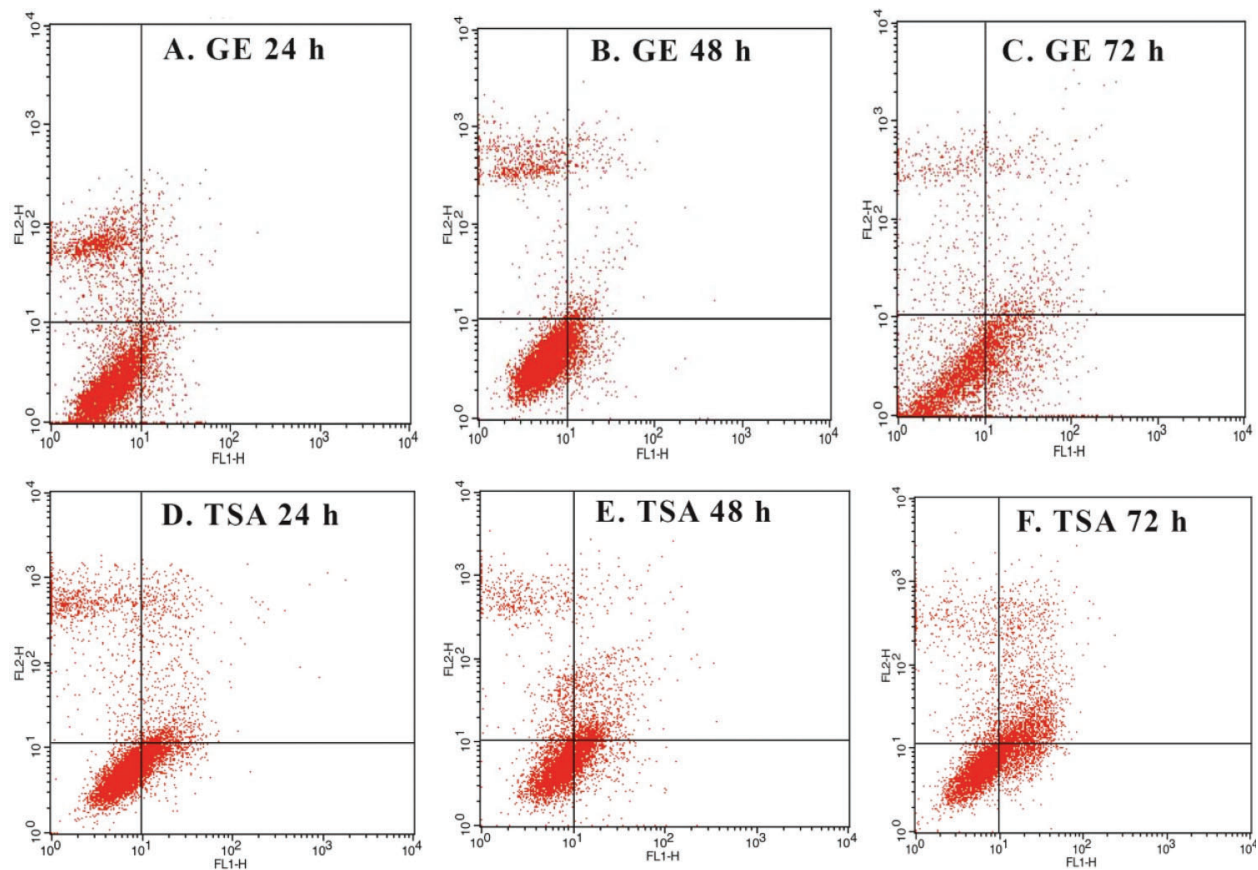

Fig. 3. Apoptotic effects of GE and TSA. Both agents induced significant apoptosis in HepG2 cells at different time periods (24, 48 and 72 h). The apoptotic cell percentage in the groups treated with TSA were more significant than that of GE at different time periods $(p<0.001)$.

Maximal apoptosis was seen in the group which received TSA for $72 \mathrm{~h}$.

\section{Discussion}

DNA methylation and histone acetylation are important regulators of gene transcription. Alterations in DNA methylation and histone acetylation are common in a variety of tumors, as well as in development. In fact, DNA hypermethylation and histone deacetylation of the promoter regions of tumor suppressor genes lead to gene silencing and play a crucial role during tumorigenesis. ${ }^{27}$ As a predominant epigenetic modification in mammals, DNA methylation at the 5-position of cytosine is catalyzed by DNMTs. ${ }^{28}$ DNMT inhibitors, such as GE, and HDACIs, such as TSA, can successfully reactivate silenced tumor suppressor genes.

Table 3. Percentage of apoptosis in the groups treated with GE and TSA at different time periods

\begin{tabular}{lllll}
\hline Drug & $\begin{array}{l}\text { Dose } \\
(\mu \mathrm{M})\end{array}$ & $\begin{array}{l}\text { Duration } \\
(\mathrm{h})\end{array}$ & $\begin{array}{l}\text { Apoptosis } \\
(\%)\end{array}$ & $\mathrm{p}$-value \\
\hline GE & 22 & 24 & 9 & $\mathrm{p}<0.001$ \\
GE & 22 & 48 & 14 & $\mathrm{p}<0.001$ \\
GE & 22 & 72 & 28 & $\mathrm{p}<0.001$ \\
TSA & 1.5 & 24 & 31 & $\mathrm{p}<0.001$ \\
TSA & 1.5 & 48 & 36 & $\mathrm{p}<0.001$ \\
TSA & 1.5 & 72 & 40 & $\mathrm{p}<0.001$ \\
\hline
\end{tabular}

In the present study, we indicated that GE and TSA inhibit cell growth and induce apoptosis in the HCC HepG2 cell line. Furthermore, the apoptotic effect of TSA was more significant than GE. Similar to our result, it has been reported that GE induces apoptosis in $\mathrm{HCC}$ MHCC $97-\mathrm{H}^{29}$ and in human prostate cancer cell lines. ${ }^{30}$ Consistent with our finding, antiproliferative and apoptotic effects of TSA on hepatoma cells has been reported. ${ }^{31}$ In addition to antiproliferative and apoptotic effects, we demonstrated that GE and TSA restored DNMT1, DNMT3a and DNMT3b gene expression significantly, which could be a possible mechanism of these compounds.

Other researchers have demonstrated that GE induces a significant decrease in the transcript levels of all the DNMTs, including DNMT1, DNMT3a and DNMT3b, in breast cancer. ${ }^{32}$ Similarly, it has been reported that TSA down-regulates DNMT1 in the HCT116 colon cancer cell line. ${ }^{33}$ One of the apoptotic pathways of GE in HCC Hep3B cells is the activation of several ER stress-relevant regulators, such as $m$-calpain, GADD153, GRP78 and caspase-12. ${ }^{34}$

Recent studies have shown that GE stimulates expression of the tumor suppressor genes $p 21^{\text {WAF1 }}$ and $p 16^{I N K 4 a}$ in breast cancer cells, which is associated with a small reduction in the activity of HDACs but a large increase in the activity of histone methyl transferases. ${ }^{35}$ It can also reactivate ER $\alpha$ expression in breast cancer cells, which in turn is associated with increased markers of histone acetylation in the ER $\alpha$ promoter region and decreased activity of HDAC and DNMT. ${ }^{36}$

One mechanism by which TSA might exert its apoptotic effect is through increasing the proapoptotic bax in hepatoma cells, which plays a central role in the release of mitochondrial cytochrome $\mathrm{C}$ into the cytosol, by which apoptosis is induced. ${ }^{37}$ Besides, TSA down-regulates antiapoptotic bcl-2 in hepatoma cells. ${ }^{38}$ In colorectal cancer cells (HCT116 cells 
and HT29 cells), it has been shown that TSA induces G2/M cell cycle arrest and bax-dependent apoptosis by both p53dependent and -independent mechanisms. ${ }^{39}$ TSA induction of p21WAF1, which plays an essential role in G1 and G2 arrests, has been reported in bladder cancer cells, ${ }^{40}$ pancreatic adenocarcinoma cells, ${ }^{41}$ brain tumor cells ${ }^{42}$ and colon carcinoma cells. ${ }^{43}$ This induction is the result of increased acetylation of histone 3 and histone 4 associated with p21WAF1 gene promoter, ${ }^{44,45}$ resulting in an open chromatin structure and enhanced transcription.

Many studies have reported that GE has biphasic (inhibitory and proliferative) effect. Previously, we reported the apoptotic effect of GE with $25 \mu \mathrm{M}$ and $20 \mu \mathrm{M}$ concentrations on PLC/PRF5 and HepG2 HCC cell lines respectively. 7,8 Opposite of these reports, it has been shown that GE can induce apoptosis in the prostatic cancer LAPC-4 cells, but has a biphasic effect on the LNCap cell line. In fact, this agent has a proliferative effect with physiological concentration $(<10 \mu \mathrm{M})$ and inhibitory response with high concentration ( $25 \mu \mathrm{M}$ or $>25$ $\mu \mathrm{M}) .{ }^{46}$ Besides, a proliferative effect of GE with $3.7 \mu \mathrm{M}$ concentration and an inhibitory effect with 26-111 $\mu \mathrm{M}$ concentration in human intestinal cells has been reported. Moreover, this compound can stimulate cell growth with $<3.7 \mu \mathrm{M}$ concentration in the IEC18 cell line ${ }^{47}$ and also stimulate cell proliferation in ER-positive MCF-7 breast carcinoma cells with 1 $\mathrm{nM}$ to $10 \mu \mathrm{M} / \mathrm{L}$ concentrations. ${ }^{48}$

As an HDACI, TSA induces apoptosis in a dose-dependent manner. In the current study, we indicated that it induced apoptosis with a concentration of $1.5 \mu \mathrm{M}$. Previously, we demonstrated that TSA induced apoptosis with a concentration of $1 \mu \mathrm{M}$ in the HepG2 cell line. ${ }^{22}$ Other studies have reported that it induces apoptosis in renal carcinoma ACHN, Caki-1, Caki-2 and A498 cells with $125-250 \mathrm{nM}$ concentration in a dose-dependent manner ${ }^{49}$ and also in non-small cell lung cancer lines with $0.01 \mu \mathrm{mol} / \mathrm{L}$ to $0.04 \mu \mathrm{mol} / \mathrm{L}$ concentrations. ${ }^{50}$

Our finding indicated that TSA strongly induced apoptosis and that the ability of TSA to induce apoptosis was greater than that of GE, whereas the effect of TSA on DNMTs gene expression was less than that of GE. In addition to reactivation of DNMTs, TSA may, therefore, increase apoptosis by other mechanisms, such as acetylation of $p 53,{ }^{51}$ generation of DNA fragmentation, activation of procaspase-3, cleavage of PARP, and increase of DNA hypoploidy. ${ }^{52}$ Taken together, our data indicate that GE and TSA can reactivate DNMT1, DNMT3a and DNMT3b, thereby inducing apoptosis. Besides, the apoptotic effect of TSA was more significant than that of GE. We did not, however, evaluate protein assessment and acetylation status in this study, and it will be a subject of separate research.

\section{Conclusions}

Collectively, our findings suggest an important role of GE and TSA on apoptosis induction by reactivation of DNMT1, DNMT3a and DNMT3b gene expression. The function of GE and TSA in inducing apoptosis via DNMTs inhibition is very important since it may provide new preventive and therapeutic strategies for cancer treatment.

\section{Acknowledgments}

This article was supported by adjutancy of research of Jahrom Medical University-Iran.

\section{Conflict of interest}

The authors have no conflict of interests related to this publication.

\section{Author contributions}

Generation of the ideas and writing of the manuscript (MS, $\mathrm{FK}, \mathrm{AR}, \mathrm{FG}$ ), literature search and data collation (MS), data verification and guarantor for the manuscript (FK). All authors read and approved the final version of the manuscript.

\section{References}

[1] Kondo Y, Shen L, Issa JP. Critical role of histone methylation in tumor suppressor gene silencing in colorectal cancer. Mol Cell Biol 2003;23:206-215. doi: 10.1128/MCB.23.1.206-215.2003.

[2] Oh BK, Kim H, Park HJ, Shim YH, Choi J, Park C, et al. DNA methyltransferase expression and DNA methylation in human hepatocellular carcinoma and their clinicopathological correlation. Int J Mol Med 2007;20:65-73. doi: 10. 3892/ijmm.20.1.65.

[3] Wang J, Eltoum IE, Lamartiniere CA. Dietary genistein suppresses chemically induced prostate cancer in Lobund-Wistar rats. Cancer Lett 2002;186:1118. doi: 10.1016/S0304-3835(01)00811-4.

[4] Hakkak R, Korourian S, Ronis MJ, Johnston JM, Badger TM. Soy protein isolate consumption protects against azoxymethane-induced colon tumors in male rats. Cancer Lett 2001;166:27-32. doi: 10.1016/S0304-3835(01) 00441-4.

[5] Ouyang G, Yao L, Ruan K, Song G, Mao Y, Bao S. Genistein induces G2/M cell cycle arrest and apoptosis of human ovarian cancer cells via activation of DNA damage checkpoint pathways. Cell Biol Int 2009;33:1237-1244. doi: 10.1016/j.cellbi.2009.08.011.

[6] Cappelletti V, Fioravanti L, Miodini P, Di Fronzo G. Genistein blocks breast cancer cells in the G(2)M phase of the cell cycle. J Cell Biochem 2000;79: 594-600. doi: 10.1002/1097-4644(20001215)79:4<594: :AID-JCB80>3.0. $\mathrm{CO} ; 2-4$

[7] Dastjerdi MN, Kavoosi F, Valiani A, Esfandiari E, Sanaei M, Sobhanian S, et al. Inhibitory effect of genistein on PLC/PRF5 hepatocellular carcinoma cell line. Int J Prev Med 2015;6:54. doi: 10.4103/2008-7802.158914.

[8] Sanaei M, Kavoosi F, Atashpour S, Haghighat S. Effects of genistein and synergistic action in combination with tamoxifen on the HepG2 human hepatocellular carcinoma cell line. Asian Pac J Cancer Prev 2017;18:2381-2385. doi: 10.22034/APJCP.2017.18.9.2381.

[9] Lee WR, Shen SC, Lin HY, Hou WC, Yang LL, Chen YC. Wogonin and fisetin induce apoptosis in human promyeloleukemic cells, accompanied by a decrease of reactive oxygen species, and activation of caspase 3 and $\mathrm{Ca}(2$ + )-dependent endonuclease. Biochem Pharmacol 2002;63:225-236. doi: 10.1016/S0006-2952(01)00876-0.

[10] Chang KL, Kung ML, Chow NH, Su SJ. Genistein arrests hepatoma cells at G2/M phase: involvement of ATM activation and upregulation of p21waf1/cip1 and Wee1. Biochem Pharmacol 2004;67:717-726. doi: 10. 1016/j.bcp.2003.10.003.

[11] Adhami VM, Ahmad N, Mukhtar H. Molecular targets for green tea in prostate cancer prevention. J Nutr 2003;133:2417S-2424S. doi: 10.1093/jn/133.7. 2417S.

[12] Kandaswami C, Lee LT, Lee PP, Hwang JJ, Ke FC, Huang YT, et al. The antitumor activities of flavonoids. In Vivo 2005;19:895-909.

[13] Hou Z, Lambert JD, Chin KV, Yang CS. Effects of tea polyphenols on signal transduction pathways related to cancer chemoprevention. Mutat Res 2004; 555:3-19. doi: 10.1016/j.mrfmmm.2004.06.040.

[14] Shimizu M, Deguchi A, Lim JT, Moriwaki H, Kopelovich L, Weinstein IB. $(-)$-Epigallocatechin gallate and polyphenon $E$ inhibit growth and activation of the epidermal growth factor receptor and human epidermal growth factor receptor-2 signaling pathways in human colon cancer cells. Clin Cancer Res 2005;11:2735-2746. doi: 10.1158/1078-0432.CCR-04-2014.

[15] Eberharter A, Becker PB. Histone acetylation: a switch between repressive and permissive chromatin. Second in review series on chromatin dynamics. EMBO Rep 2002;3:224-229. doi: 10.1093/embo-reports/kvf053.

[16] Bannister AJ, Kouzarides T. Regulation of chromatin by histone modifications. Cell Res 2011;21:381-395. doi: 10.1038/cr.2011.22.

[17] Medina V, Edmonds B, Young GP, James R, Appleton S, Zalewski PD. Induction of caspase-3 protease activity and apoptosis by butyrate and trichostatin A (inhibitors of histone deacetylase): dependence on protein synthesis and synergy with a mitochondrial/cytochrome c-dependent pathway. Cancer Res 1997;57:3697-3707. 
[18] Egger G, Liang G, Aparicio A, Jones PA. Epigenetics in human disease and prospects for epigenetic therapy. Nature 2004;429:457-463. doi: 10 . 1038 /nature02625.

[19] Xu WS, Parmigiani RB, Marks PA. Histone deacetylase inhibitors: molecular mechanisms of action. Oncogene 2007;26:5541-5552. doi: $10.1038 / \mathrm{sj}$. onc. 1210620.

[20] Shankar S, Srivastava RK. Histone deacetylase inhibitors: mechanisms and clinical significance in cancer: HDAC inhibitor-induced apoptosis. Adv Exp Med Biol 2008;615:261-298. doi: 10.1007/978-1-4020-6554-5_13.

[21] Herold C, Ganslmayer M, Ocker M, Hermann M, Geerts A, Hahn EG, et al. The histone-deacetylase inhibitor Trichostatin A blocks proliferation and triggers apoptotic programs in hepatoma cells. J Hepatol 2002;36:233-240. doi: 10. 1016/S0168-8278(01)00257-4.

[22] Sanaei M, Kavoosi F, Salehi H. Genistein and trichostatin A induction of estrogen receptor alpha gene expression, apoptosis and cell growth inhibition in hepatocellular carcinoma HepG 2 cells. Asian Pac J Cancer Prev 2017;18: 3445-3450. doi: 10.22034/APJCP.2017.18.12.3445.

[23] Shiau RJ, Chen KY, Wen YD, Chuang CH, Yeh SL. Genistein and beta-carotene enhance the growth-inhibitory effect of trichostatin A in A549 cells. Eur J Nutr 2010;49:19-25. doi: 10.1007/s00394-009-0044-8.

[24] Wu TC, Yang YC, Huang PR, Wen YD, Yeh SL. Genistein enhances the effect of trichostatin A on inhibition of A549 cell growth by increasing expression of TNF receptor-1. Toxicol Appl Pharmacol 2012;262:247-254. doi: 10.1016/j. taap.2012.05.003.

[25] Leu YW, Rahmatpanah F, Shi H, Wei SH, Liu JC, Yan PS, et al. Double RNA interference of DNMT3b and DNMT1 enhances DNA demethylation and gene reactivation. Cancer Res 2003;63:6110-6115.

[26] Lin CH, Hsieh SY, Sheen IS, Lee WC, Chen TC, Shyu WC, et al. Genome-wide hypomethylation in hepatocellular carcinogenesis. Cancer Res 2001;61: 4238-4243.

[27] Baylin SB, Ohm JE. Epigenetic gene silencing in cancer - a mechanism for early oncogenic pathway addiction? Nat Rev Cancer 2006;6:107-116. doi: $10.1038 /$ nrc1799.

[28] Subramaniam D, Thombre R, Dhar A, Anant S. DNA methyltransferases: a novel target for prevention and therapy. Front Oncol 2014;4:80. doi: 10 . 3389/fonc.2014.00080.

[29] Gu Y, Zhu CF, Dai YL, Zhong Q, Sun B. Inhibitory effects of genistein on metastasis of human hepatocellular carcinoma. World J Gastroenterol 2009;15:4952-4957.doi: 10.3748/wjg.15.4952.

[30] Shen JC, Klein RD, Wei Q, Guan Y, Contois JH, Wang TT, et al. Low-dose genistein induces cyclin-dependent kinase inhibitors and $G(1)$ cell-cycle arrest in human prostate cancer cells. Mol Carcinog 2000;29:92-102. doi: 10.1002/1098-2744(200010)29:2<92::AID-MC6>3.0.CO;2-Q.

[31] Papeleu P, Vanhaecke T, Elaut G, Vinken M, Henkens T, Snykers S, et al. Differential effects of histone deacetylase inhibitors in tumor and normal cells-what is the toxicological relevance? Crit Rev Toxicol 2005;35:363378. doi: $10.1080 / 10408440590935639$.

[32] Mirza S, Sharma G, Parshad R, Gupta SD, Pandya P, Ralhan R. Expression of DNA methyltransferases in breast cancer patients and to analyze the effect of natural compounds on DNA methyltransferases and associated proteins. J Breast Cancer 2013;16:23-31. doi: 10.4048/jbc.2013.16.1.23..

[33] Choi JH, Min NY, Park J, Kim JH, Park SH, Ko Y], et al. TSA-induced DNMT1 down-regulation represses hTERT expression via recruiting CTCF into demethylated core promoter region of hTERT in HCT116. Biochem Biophys Res Commun 2010;391:449-454. doi: 10.1016/j.bbrc.2009.11.078.

[34] Yeh TC, Chiang PC, Li TK, Hsu JL, Lin CJ, Wang SW, et al. Genistein induces apoptosis in human hepatocellular carcinomas via interaction of endoplasmic reticulum stress and mitochondrial insult. Biochem Pharmacol 2007;73: 782-792. doi: 10.1016/j.bcp.2006.11.027.

[35] Li Y, Chen H, Hardy TM, Tollefsbol TO. Epigenetic regulation of multiple tumor-related genes leads to suppression of breast tumorigenesis by dietary genistein. PLoS One 2013;8:e54369. doi: 10.1371/journal.pone. 0054369.

[36] Li Y, Meeran SM, Patel SN, Chen H, Hardy TM, Tollefsbol TO. Epigenetic reactivation of estrogen receptor- $\alpha(E R \alpha)$ by genistein enhances hormonal therapy sensitivity in $E R \alpha$-negative breast cancer. Mol Cancer 2013;12:9. doi: 10.1186/1476-4598-12-9.

[37] Bedner E, Li X, Kunicki J, Darzynkiewicz Z. Translocation of Bax to mitochondria during apoptosis measured by laser scanning cytometry. Cytometry 2000;41:83-88. doi: 10.1002/1097-0320(20001001)41:2<83::AIDCYTO1>3.0.CO;2-R.

[38] Francis JM, Heyworth CM, Spooncer E, Pierce A, Dexter TM, Whetton AD. Transforming growth factor-beta 1 induces apoptosis independently of p53 and selectively reduces expression of $\mathrm{Bcl}-2$ in multipotent hematopoietic cells. J Biol Chem 2000;275:39137-39145. doi: 10.1074/jbc. M007212200.

[39] Meng J, Zhang HH, Zhou CX, Li C, Zhang F, Mei QB. The histone deacetylase inhibitor trichostatin $\mathrm{A}$ induces cell cycle arrest and apoptosis in colorectal cancer cells via p53-dependent and -independent pathways. Oncol Rep 2012;28:384-388. doi: 10.3892/or.2012.1793.

[40] Li GC, Zhang X, Pan TJ, Chen Z, Ye ZQ. Histone deacetylase inhibitor trichostatin $A$ inhibits the growth of bladder cancer cells through induction of p21WAF1 and G1 cell cycle arrest. Int J Urol 2006;13:581-586. doi: 10. 1111/j.1442-2042.2006.01344.x.

[41] Donadelli M, Costanzo C, Faggioli L, Scupoli MT, Moore PS, Bassi C, et al. Trichostatin A, an inhibitor of histone deacetylases, strongly suppresses growth of pancreatic adenocarcinoma cells. Mol Carcinog 2003;38:59-69. doi: $10.1002 / \mathrm{mc} .10145$.

[42] Wang ZM, Hu J, Zhou D, Xu ZY, Panasci LC, Chen ZP. Trichostatin A inhibits proliferation and induces expression of p21WAF and p27 in human brain tumor cell lines. Ai Zheng 2002;21:1100-1105.

[43] Chen Z, Clark S, Birkeland M, Sung CM, Lago A, Liu R, et al. Induction and superinduction of growth arrest and DNA damage gene 45 (GADD45) alpha and beta messenger RNAs by histone deacetylase inhibitors trichostatin A (TSA) and butyrate in SW620 human colon carcinoma cells. Cancer Lett 2002;188:127-140. doi: 10.1016/S0304-3835(02)00322-1.

[44] Gui CY, Ngo L, Xu WS, Richon VM, Marks PA. Histone deacetylase (HDAC) inhibitor activation of p21WAF1 involves changes in promoter-associated proteins, including HDAC1. Proc Natl Acad Sci U S A 2004;101:12411246. doi: 10.1073/pnas.0307708100.

[45] Richon VM, Sandhoff TW, Rifkind RA, Marks PA. Histone deacetylase inhibitor selectively induces p21WAF1 expression and gene-associated histone acetylation. Proc Natl Acad Sci U S A 2000;97:10014-10019. doi: 10. 1073/pnas.180316197.

[46] Abdalla A, Darwish A, Elbanhawy R, Ghouraba A, Shehata S. Hepatocellular carcinoma: An overview of disease epidemiology and risk factors. Int J Allied Med Sci Clin Res 2014;2:205-209.

[47] Nigam N, George J, Srivastava S, Roy P, Bhui K, Singh M, et al. Induction of apoptosis by [6]-gingerol associated with the modulation of $\mathrm{p} 53$ and involvement of mitochondrial signaling pathway in $\mathrm{B}[\mathrm{a}] \mathrm{P}$-induced mouse skin tumorigenesis. Cancer Chemother Pharmacol 2010;65:687-696. doi: 10. 1007/s00280-009-1074-x.

[48] Chen AC, Donovan SM. Genistein at a concentration present in soy infant formula inhibits Caco-2BBe cell proliferation by causing G2/M cell cycle arrest. J Nutr 2004;134:1303-1308. doi: 10.1093/jn/134.6.1303.

[49] Park WH, Jung CW, Park JO, Kim K, Kim WS, Im YH, et al. Trichostatin inhibits the growth of ACHN renal cell carcinoma cells via cell cycle arrest in association with p27, or apoptosis. Int J Oncol 2003;22:1129-1134. doi: 10. 3892/ijo.22.5.1129.

[50] Mukhopadhyay NK, Weisberg E, Gilchrist D, Bueno R, Sugarbaker DJ, Jaklitsch MT. Effectiveness of trichostatin $A$ as a potential candidate for anticancer therapy in non-small-cell lung cancer. Ann Thorac Surg 2006;81: 1034-1042. doi: 10.1016/j.athoracsur.2005.06.059.

[51] Fortson WS, Kayarthodi S, Fujimura $Y, X u$ H, Matthews R, Grizzle WE, et al. Histone deacetylase inhibitors, valproic acid and trichostatin-A induce apoptosis and affect acetylation status of p53 in ERG-positive prostate cancer cells. Int J Oncol 2011;39:111-119. doi: 10.3892/ijo.2011.1014.

[52] Roh MS, Kim CW, Park BS, Kim GC, Jeong JH, Kwon HC, et al. Mechanism of histone deacetylase inhibitor Trichostatin $\mathrm{A}$ induced apoptosis in human osteosarcoma cells. Apoptosis 2004;9:583-589. doi: 10.1023/B:APPT. $0000038037.68908 .6 \mathrm{e}$ 